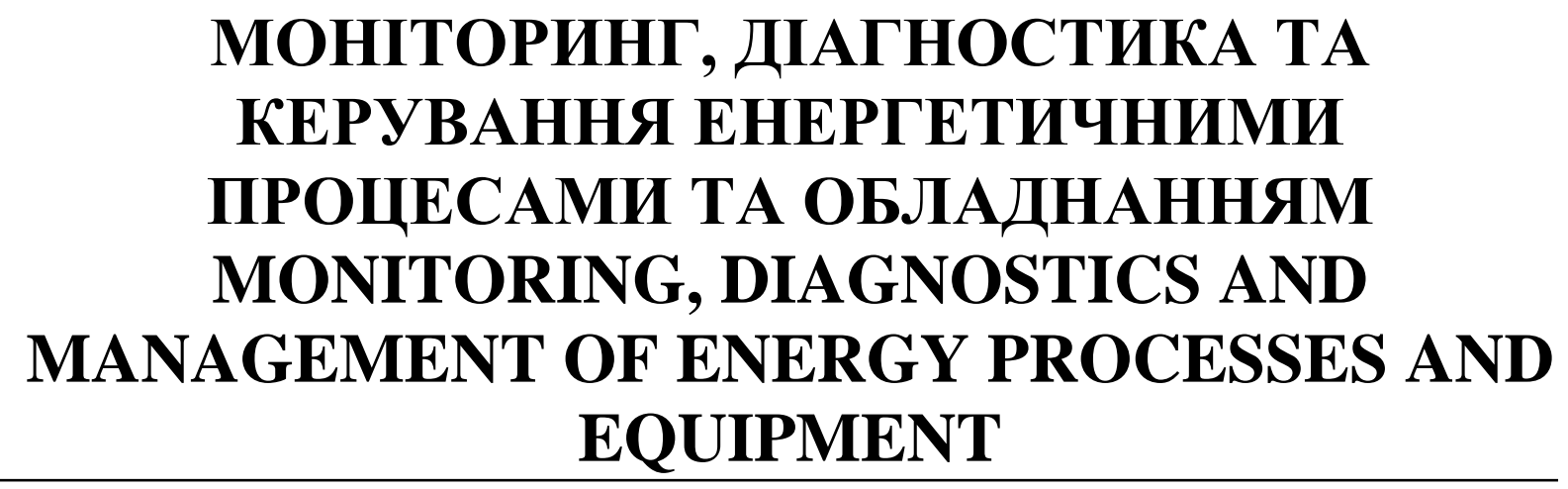

S. Shevchuk, Prof. Dr., ORCID 0000-0002-7517-0501

S. Zaichenko, Prof. Dr., ORCID 0000-0002-8446-5408 National Technical University of Ukraine «Igor Sikorsky Kyiv Polytechnic Institute»

\title{
SECURING RELIABILITY AND JUSTIFICATION OF SERVICE LIFE OF ELECTROMECHANICAL EQUIPMENT FOR ELEVATOR GROUP OF A MULTI FLOOR BUILDING
}

\begin{abstract}
Elevators belong to the high risk mechanisms, so their reliable and safe operation is an important task in the construction of various real estate objects, especially multi-storey buildings. Ensuring for the reliable operation of elevators can be done in different ways. This is first of all the use of modern highly reliable electromechanical equipment and technologies for the manufacture and installation of elevator installations, the use of non-traditional kinematic circuits of the structural device of elevators, which allow to reduce the number of units of equipment in the elevator installation. And in the period of operation is the use of effective systems of technical diagnostics, maintenance and repair in order to prevent equipment failures and timely and quality updating.

The booking of elevators number, in more than 2 or 3 installations in the group of elevators of a single building gives a significant result in improving of the reliability of the operation of elevators of multi-storey buildings, that simultaneously contributes to reducing the period of time for applications for the carriage of passengers. For countries such as Ukraine, the problem of operating an elevator system is the outdated fleet of existing elevators, exceeding of the regulatory terms of their operation with the simultaneous mass growth of new buildings, in addition, further complicated by the lack of a sufficient number of qualified maintenance staff with sufficient material incentives and outflow. Therefore, the urgent problems of the present are the establishment of reasonable operating times of single elevator installations, reliability indicators of the group of elevators, the optimal amount of their reservation, ensuring their diagnostics and reforming of the maintenance and repair system in accordance with the features of today's requirements of operation of a complex elevator economy as an important component of high-functioning infrastructure cities. These studies are carried out with the application of queuing theory and reliability of reserved passenger transportation systems, analytical methods for investigating of the technical reliability of the operation for elevator installations.
\end{abstract}

Keywords: elevator group, indicators of reliability, failure rate, renewal rate, status graph, readiness function, readiness factor, service life.

Introduction. The most common of all types of elevators are passenger elevators, which are found in every high-rise building. 20.3 million elevators are operated worldwide, China is the leader in the number of elevators 4.67 million elevators ( $23 \%$ of the world). There are 6.1 million elevators operating in Europe, 1 million elevators in the United States, $9 \%$ of them are in New York. There are 86,000 elevators in Ukraine, of which $60 \%$ have been in operation for over 25 years. There are 22,428 elevators operated in Kyiv, of which 10,404 elevators (46.4\%) have been in operation for over 25 years (in the year 2017). The most powerful elevator manufacturers are: OTIS, Swissbased Schindler, Asian companies Toshiba, Hyundai, Mitsubishi, Thyssen Krupp - Germany, KONE - Finland; in the post-soviet area - Mogilev, Karacharovsky and Shcherbinsky elevator plants.

There is a tendency of mass growth of the elevator park with a simultaneous insufficient number of qualified service personnel to date, which requires the creation of the more modern system for routine preventive works, maintenance, diagnosis and repair.

The main qualitative indicators of the functioning of passenger lifts is the safety and reliability of their

(C) С.П. Шевчук, С.В. Зайченко, 2019 
operation. There are some contradictions between these indicators. Thus, more sophisticated designs, control circuits and elevator protection are achieved by increasing safety, which, on the other hand, causes a decrease in the reliability of the installation. The elevator installation is a complex mechatronic system [1], reliable operation of which is determined not only by the reliability of the equipment, the system of maintenance and repair, but also by a number of factors of external influence- change of temperature, which promotes the appearance of condensate, dust, vibration, vandalism and more. Single reliability indicators of elevators can serve: probability of failure-free operation, intensity of failures, intensity of updates, term of time to failure and others. Complex reliability indicators include: the readiness function and the readiness factor.

An elevator is a complex electromechanical system with serially connected elements (Fig. 1). Failure of any elements cause the entire installation to fail. The reducing of the number of nodes will lead to increased reliability, so the progressive directions of creating modern lifting installations are [2-5]: gearless winch with frequency-controlled motor, endless lift with the use of a linear motor on the elevator cabin (Mitsubishi Electric Corporation). Advantages of such installations: absence of ropes, reducer, counterweights. The downside is the high power of the drive, which reduces safety.

Reserving of the number of elevators (group of elevators) in multi-story buildings significantly increases the functional reliability for passenger transportation, but leads to more expensive buildings. Finding a compromise between cost and reliability indicators is unlikely, but at least quantifying the values of reliability indicators for their future legislative approval is an urgent scientific and technical challenge today.

On the other hand, the growth of the elevator park, their unit price and the limited working capital make it impossible for them to be dismantled and replaced in timely manner, which facilitates the operation of the elevators by exceeding the regulatory terms of their operation and reducing the reliability and safety indicators.

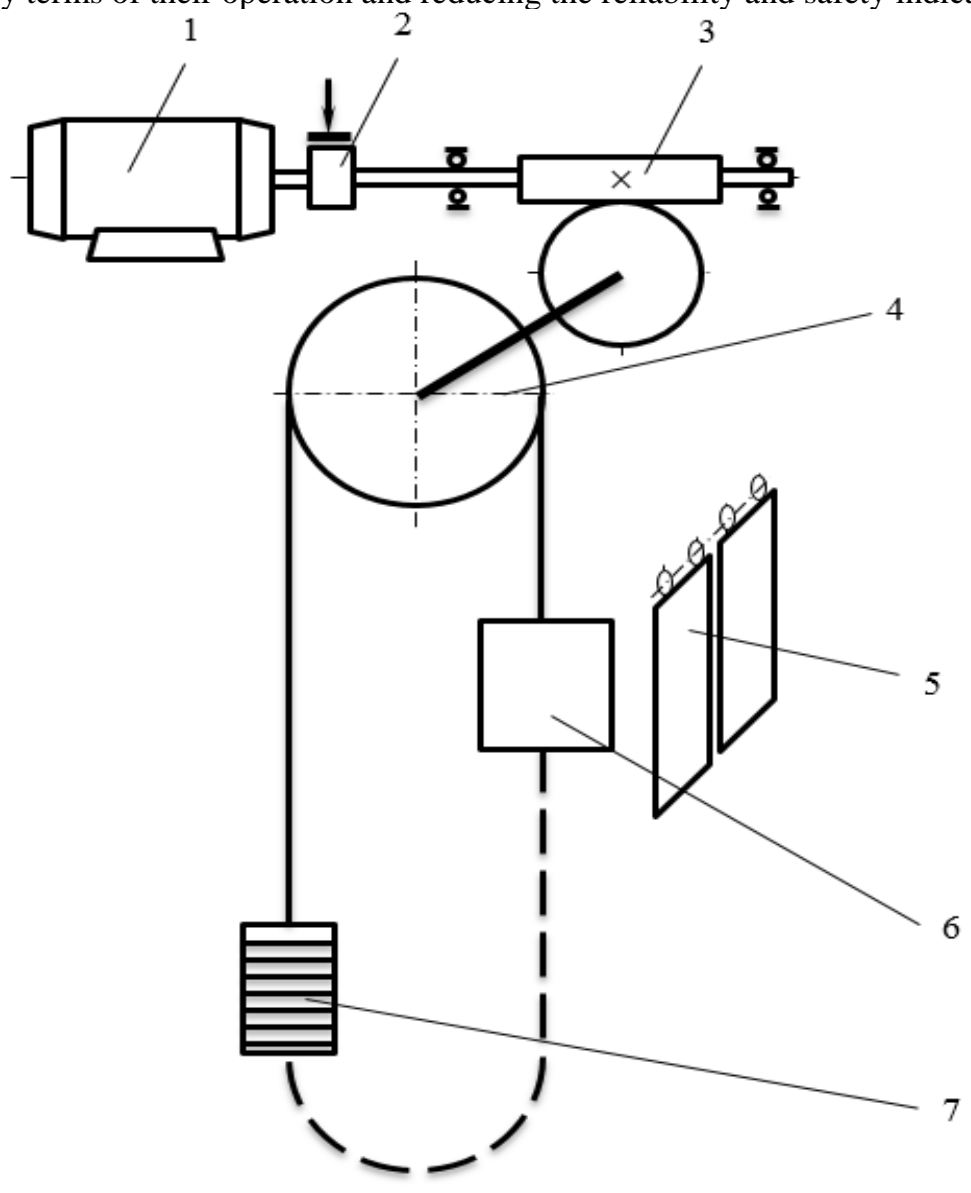

Fig. 1 Elevator installation scheme:

1- electric motor; 2- clutch with brake; 3 - gear; 4 - a friction pulley; 5 - door block; 6 - a cabin for passengers; 7 - counterweight

Today there is no justification for the lifespan of elevators with specified reliability and safety indicators. Technical regulations of the Customs Union [6] set the total lifespan of all types of elevators in 25 years, which cannot be considered justified.

The goal of the work. To obtain quantitative values for the reliability of the elevator group, depending on the number of elevators in the group, and justify their lifespan. 
The idea of the work is to establish in a statistical way the dependence of the reliability of the elevator group on the number of elevators in this group, as well as to justify the end-of-life of the elevator group, based on the criterion of performance of at least one elevator from the group. It was proposed to take the group of elevators as considered functionally operable to the operating time to failure of at least one elevator from the group exceeds the renewal time of other elevators after their simultaneous failure.

Materials and methods. According to State standards DSTU 2860-94, a group of elevators in a multi-story building should be classified as a variable-reserve facility, the bulk of the equipment operating in a loaded reserve for the purpose of faster passenger service. Therefore, the main research method is the theory of reliability of redundant systems with elements of the theory of probability and the analytical method of studying the reliability indicators of elevators.

A quality maintenance and repair system (MRS) is of particular importance in ensuring the reliable operation of elevators. We should bear in mind that due to the limited availability of qualified service personnel of the elevators for MRS is carried out by the mass service system (MSS) with expectation, and more specifically - by the MSS with unlimited expectation, when there are successive periods of time for normal operation of the elevator, exit it is out of order, waiting periods and repairs.

Research results. As each elevator in the group consists of consecutively connected nodes, so the troublefree operation of the elevator is possible with the trouble-free operation of each node. Assuming that the possible failures of the nodes are independent, then the failure rate of the elevator $\lambda(t)$ is equal to the sum of the intensity of its nodes $\lambda_{i}(t)$ at any distribution of the output of the nodes before the operation time to failure.

$$
\lambda(t)=\sum_{i=1}^{n} \lambda_{i}(t)
$$

Figure 2 shows a typical failure rate function, which shows three periods of I - flushing; II - normal operation; III - aging. In the period of III, there has been an over-standard operation of elevators for more than 25 years. Time to failure (in case of exponential random of distribution law) will be

$$
T_{f}=1 / \lambda \text {. }
$$

The dependence of this indicator of the reliability of the elevator on the operating time is shown by the dashed line in Fig. 2.

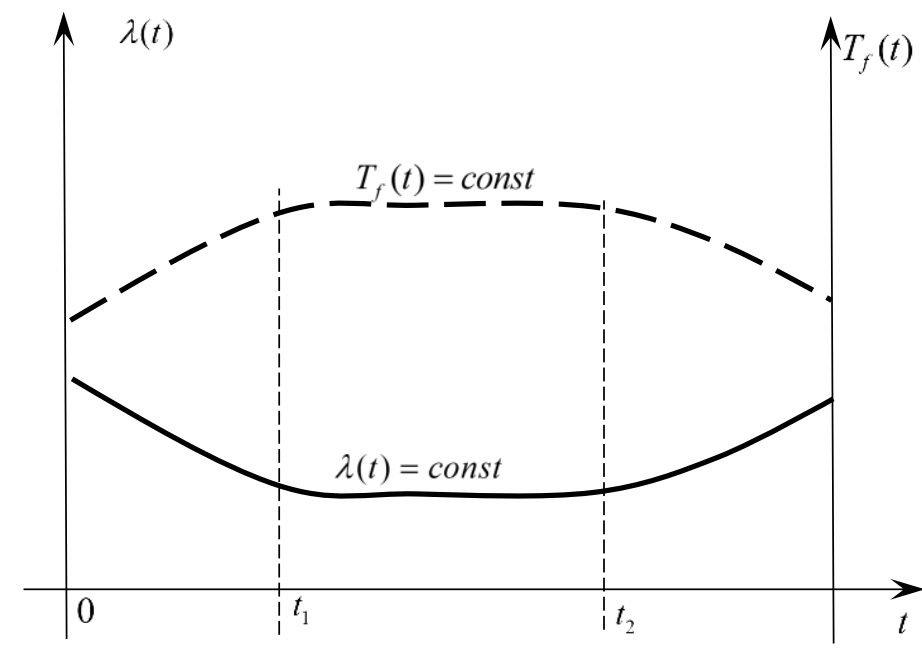

Fig. 2 Dependence of average intensity and time of work before the average period of exploitation

Intensity of renewal of work of the elevator $\boldsymbol{U}_{\text {for troubleshooting of its work - inversely proportional to }}$ the period of renewal $T_{r}$

$$
\mu=1 / T_{r} ; T_{r}=T_{w}+T_{r e p}
$$


where $T_{w}$ - the period of waiting time from the moment of failure of the lift and before its repair (according to the theory of QMS with expectation); $T_{\text {rep - period of time of repair of the lift. }}$

The readiness function $G(t)$ is a complex index of reliability because it depends on the characteristics of renewal and uptime. As a rule, the ready function has the form shown in Fig. 3. The coefficient of readiness $\mathrm{Kg}$ represents the asymptotic (constant) value of the function of readiness with unlimited time growth $-t \rightarrow \infty$ (fig. 3).

Fig. 3 Readiness function

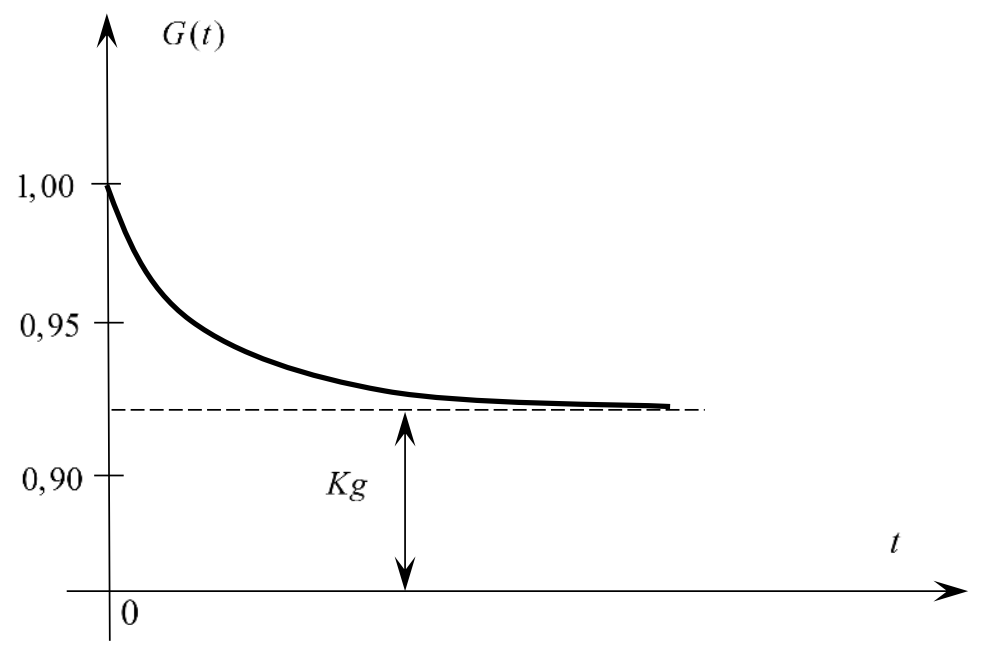

Readiness function and readiness factor for a single lift from a group of elevators will be written:

$$
\begin{gathered}
G_{o}(t)=\frac{\mu}{\lambda+\mu}+\frac{\lambda}{\lambda+\mu} \cdot e^{-(\lambda+\mu) t}, \\
K_{g}^{o}=\lim \Gamma_{o}(t)=\frac{\mu}{\lambda+\mu} .
\end{gathered}
$$

To obtain the dependence of the readiness function for a group of elevators, we use the differential equation method for the possible variants of the technical states of such a system, as shown by the corresponding state graphs in Fig. 4 (in case for two lifts).

The system of differential equations, for example, for the case of the state of a group of elevators according to the graph in Fig. 4, is written in the form

$$
\begin{gathered}
P_{o}(t)=\lambda \cdot P_{o}(t)+\mu \cdot P_{1}(t) \\
P_{1}(t)=\lambda \cdot P_{o}(t)-\lambda \cdot P_{1}(t)-\mu \cdot P_{1}(t)-2 \mu \cdot P_{2}(t), \\
P_{2}(t)=\lambda \cdot P_{1}(t)-2 \mu \cdot P_{2}(t)
\end{gathered}
$$

To solve the system of differential equations (5) it is necessary to consider that $P_{0}+P_{1}+P_{2}=1$ and initial conditions at $t=0: P_{0}(0)=1, P_{1}(0)=P_{2}(0)=0$.

Using the forward and reverse Laplace transforms, we will obtain:

$$
\begin{gathered}
G_{c}(t)=1-\frac{\lambda^{2}}{(\lambda+\mu)^{2}+\mu^{2}} \cdot\left[1+\frac{1}{\sqrt{\mu^{2}+4 \lambda \mu}} \cdot\left(y_{2} \cdot e^{y_{1} t}-y_{1} \cdot e^{y_{2} t}\right)\right], \\
K_{g}^{c} \frac{(1+\lambda / \mu)}{(1+\lambda / \mu)^{2}+1}, \\
\text { where } \quad y_{1}, 2=-\frac{2 \lambda+3 \mu \pm \sqrt{\mu^{2}+4 \lambda \mu}}{2} .
\end{gathered}
$$


The reliability indicators for the other service options are solved analytically, they are shown in Fig. 4,a,b,c $-G_{a}(t), K_{g}^{a}, G_{b}(t), K_{g}^{b}$.

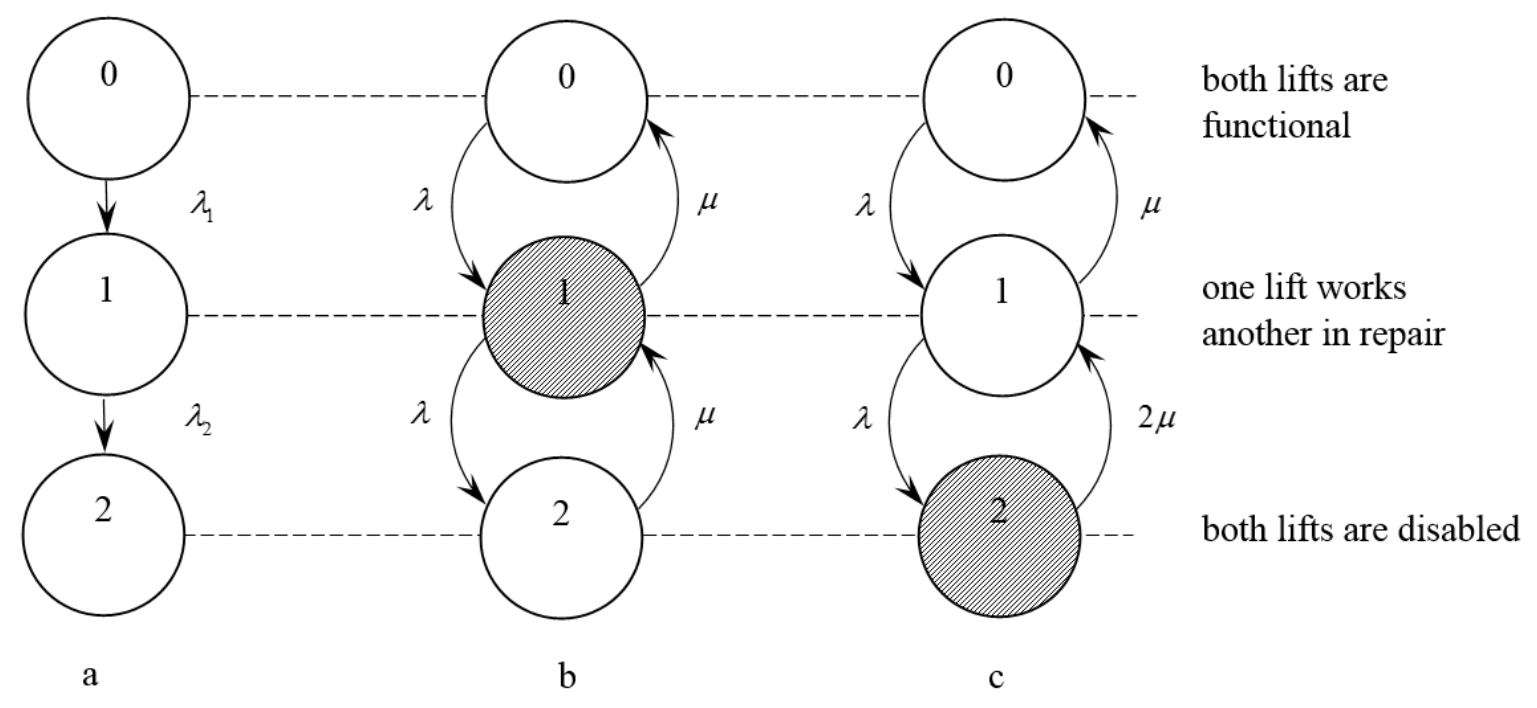

Fig. 4 status graphs of the elevator group : $a$ - without updating; $b$ - with renewal; $c$ - with unlimited updates

The group of elevators must function smoothly between the repairs of each of the elevators. To determine the conditions for the probability of such trouble-free operation state 2 on the graphs of Fig. $4, a, b$ must be absorbing, which is reflected by the risks. Performing actions similar to (5), (6), we will obtain

$$
P_{a, b}(t)=\frac{1}{Z_{2}-Z_{1}} \cdot\left(Z_{2} \cdot e^{Z_{l^{t}}}-Z_{1} \cdot e^{Z_{2 t}}\right),
$$

where $Z_{1,2}=-\frac{\mu+2 \lambda \pm \sqrt{\mu^{2}+4 \lambda \mu}}{2}$.

The result (8) allows us to determine the average uptime of a group of elevators

$$
T_{f}=\int_{0}^{\infty} P(t) d t ; \quad T_{f}^{a}=\frac{3}{2 \lambda} ; \quad T_{f}^{b}=\frac{\mu+2 \lambda}{\lambda^{2}} .
$$

The time increasing to failure will be:

$$
\frac{T_{f}^{b}}{T_{f}^{a}}=\frac{2(\mu+2 \lambda)}{3 \lambda} .
$$

Thus, at values $\lambda=0,051 h^{-1}, \mu=0,11 h^{-1}$ the average uptime of (10) is increased three times, which shows the significant advantages of the reliability index of the redundant system of two elevators when their working time (quality system of MR) is renewed.

Fig. 5 shows the dependences of the readiness functions $G(t)$ determined for the states according to Fig. 4 , $a, b, c$, as well as for a single elevator $G_{o}(t)$ by (4) at the same values $\lambda$ and $\boldsymbol{\mu}$ to compare the different renewal options and the number of lifts in the group The readiness coefficients are: $k g^{0}=0.67, \mathrm{~kg}^{a}=0.72, \mathrm{~kg}^{b}=0.85, \quad \mathrm{~kg}^{c}$ $=0.92$.

The refore, the highest reliability rates are found for a group of 2 or more elevators with an after-failure system without restriction (function $G_{c}$, coefficient of readiness $K g^{c}=0,92$ ).

Taking into account the possibility of secondary and multiple failures, as well as the possibility of irreversible functional damage of the elevators during their wear during operation, there is a gradual irreversible. reduction to the cutting to the failures of $T_{f}(2),(9)$ and the increase of periods of renewal after failures of $T_{f}(3)$. Changes in these indicators are shown in Fig. 6 for two and three lifts in the group.

In this case, the coefficient of readiness $K g$ through these indicators with (3) is expressed

$$
K_{g}=\frac{T_{f}}{T_{f}+T_{r}}=\frac{T_{f}}{T_{f}+T_{w}+T_{r e p}} .
$$




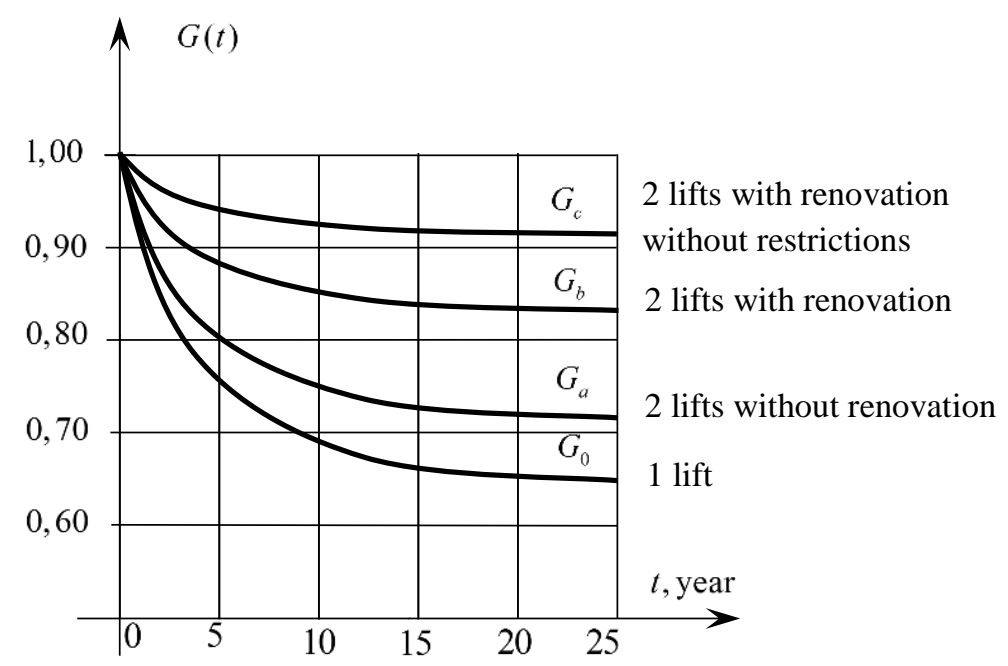

Fig. 5. Function graphs of the elevators readiness for various upgrade options

$\mathrm{Kg}$ decreases at considerable periods of operation of elevators, especially more than 25 years, at the expense of the numerator (decrease of $T_{f}$ ), and at the expense of the denominator (increase of $T_{\text {rep }}$ ).

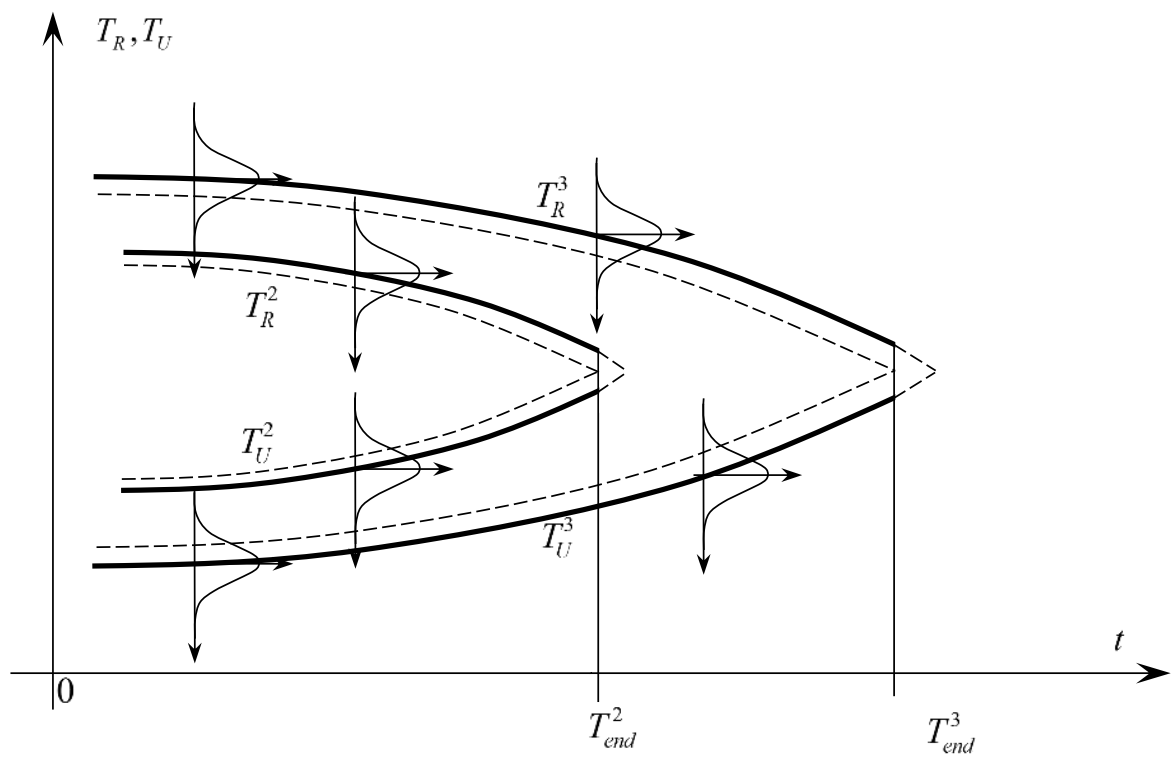

Fig. 6. Trends in changing of probable trial periods for $T_{f}$ and failure refurbishment $T_{r}$ for groups of two and three elevators

There is a trend of changes of the indicators of $T_{f}$ and $T_{r}$ (Fig. 6), their equality is critical when the working time for failure of one lift becomes equal to or less than the period of repair of the damaged elevator, and the group of elevators becomes functionally disabled. The periods $T_{\text {end }}{ }^{2}, T_{\text {end }}{ }^{3}$ should be considered as the end-oflife of a group of elevators, followed by their replacement.

Conclusions. Reserving up of two or three elevators in a group provides a significant increase in reliability if maintainance and repair is quality with unrestricted upgrade. At the same time,there is a rather high coefficient of readiness $K_{g}=0,92$, which is advisable to be fixed in the Technical Conditions as a standard set of reliability indicator with the possibility of differentiating its values for different types of elevators and features of their operation.

Supposing the technical condition of the elevators group remains safe for the carriage of passengers, then the deadline for their service should be considered to be the point in time when the period of renewal of the damaged 
elevator exceeds the period of failure of another working elevator. There is a period of time when the repair periods of both elevators overlap, and the functional purpose of the whole group of elevators is lost.

\title{
REFERENCES
}

1. Arkhangelsky, G.G., Volkov, D.P., Gorbunov, E.A., Ionov, A.A., Tkachenko, V. Ya., \& Chutchikov, P.I. (1999). Lifts. / Ed. DP Volkova. Publishing house DIA.

2. Stepanov, M.A., \& Mechiev, A.V. (2014). Failure analysis during the operation of elevators. Mechanization of construction, (8), 44-46.

3. Stepanov, M.A., \& Mechiev, A.V. (2016). Modeling of the system of maintenance of the lift park. Scientific Review, (3), 27-31.

4. Stepanov, M.A., \& Mechiev, A.V. (2016). Determination of the optimal structure of the elevator fleet using the criterion of technical and economic efficiency. Mechanization of construction, 77 (7), 49-51.

5. Mechiev, A.V., Sevryugin, N.S., \& Stepanov, M.A. (2017). General methodological approach to assessing the risk of ensuring the structural safety of elevators. Mechanization of construction, 78 (4), 24-29.

6. Technical regulations of the Customs Union (TR CU 011/2011). "Safety of elevators."

С.П. Шевчук, проф. д-р, ORCID 0000-0002-7517-0501

С.В. Зайченко, проф. д-р, ORCID 0000-0002-8446-5408

Національний технічний університет України «Київський політехнічний інститут імені Ігоря Сікорського»

\section{ЗАБЕЗПЕЧЕННЯ НАДІЙНОСТІ ТА ОБГРУНТУВАННЯ ТЕРМІНУ СЛУЖБИ ЕЛЕКТРОМЕХАНІЧНОГО ОБЛАДНАННЯ ГРУПИ ЛІФТІВ БАГАТОПОВЕРХОВОГО БУДИНКУ}

\begin{abstract}
Ліфти належать до механізмів підвищенної небезпеки, тому надійна та безпечна їх експлуатація є важливим завданням при зведенні різних об'єктів нерухомості, особливо багатоповерхових будівель. Забезпечення надійної експлуатації ліфтів може здійснюватися різними иляхами. Це пери за все застосування сучасного високонадійного електромеханічного обладнання $і$ технологій виготовлення та монтажу ліфтових установок, застосування нетрадиційних кінематичних схем конструктивного влаштування ліфтів, які дозволяють зменшити кількість одиниць обладнання в ліфтовій установці. А в період експлуатації - це застосування ефективних систем технічного діагностування, обслуговування $i$ ремонту з метою упередження відмов обладнання та своєчасного і якісного його поновлення.

Суттєвий результат в підвищенні надійності експлуатаиіі ліфтів багатоповерхових будівель надає резервування їх кількості, до більше ніж 2,3 установки в групі ліфтів окремої будівлі, щуо одночасно сприяє скороченню терміну часу виконання заявок на перевезення пасажирів. Для таких країн, як Украӥна, проблемою експлуатації ліфтового господарства являється застарілість парку існуючих ліфтів, перевищення нормативних термінів їх експлуатації з одночасним масовим ростом новобудов, щуо крім того додатково ускладнюється відсутністю достатньої кількості кваліфікованого обслуговуючого персоналу 3 їх достатнім матеріальним заохоченням та відтоком працездатного населення. Тому нагальними проблемами сьогодення являється встановлення обгрунтованих термінів експлуатачії одиночних ліфтових установок, показників надійності експлуатації групи ліфтів, оптимальної кількості їх резервування, забезпечення їх діагностування та реформування системи технічного обслуговування $i$ ремонту $y$ відповідності з особливостями сьогоденних вимог експлуатації складного ліфтового господарства як важливої складової інфраструктури функціонування високонаселених міст. Ці дослідження в роботі проводяться із застосуванням теорії масового обслуговування та забезпечення надійності резервованих систем обслуговування пасажироперевезень, аналітичних методів дослідження технічної надійності функціонування ліфтових установок.
\end{abstract}

Ключові слова: група ліфтів, показники надійності, інтенсивність відмов, інтенсивність поновлення, граф стану, функція готовності, коефіцієнт готовності, термін служби. 